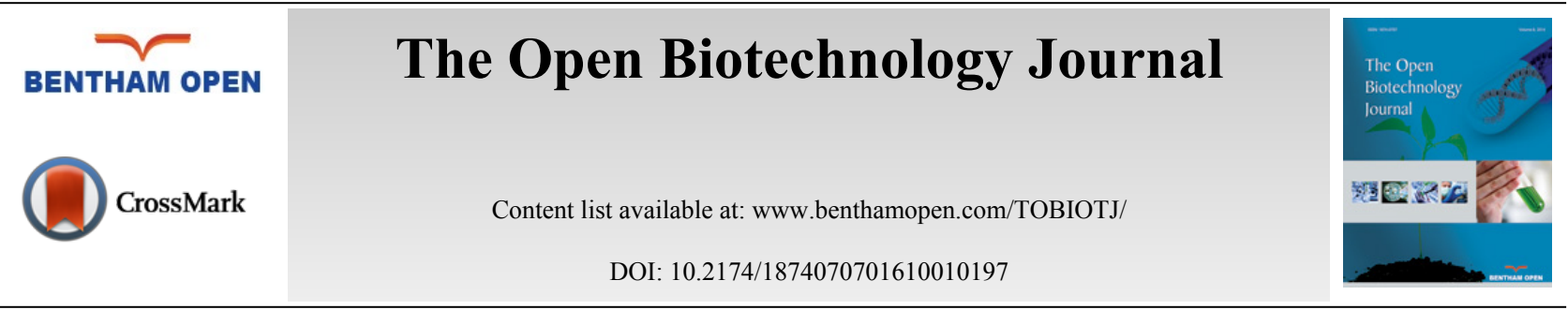

\title{
Retraction Notice: Experimental and Numerical Analysis of Drip Tape Layout for Irrigation of Sugarcane in Latosol
}

Kai Huang ${ }^{1,2, *}$, Desuo Cai ${ }^{1}$, Jinchuang Guo ${ }^{2}$ and Wei Pan ${ }^{2}$

${ }^{l}$ College of Civil Engineering and Architecture, Guangxi University, Nanning 530004, China;

${ }^{2}$ Guangxi Institute of Hydraulic Research, Nanning 530023, China

\section{RETRACTION}

The Publisher and Editor have retracted this article [1] in accordance with good ethical practices. After thorough investigations we believe that the peer review process was compromised. The article was published online on 12-11-2015.

\section{REFERENCE}

[1] Huang K, Cai D, Guo J, Pan W. Experimental and numerical analysis of drip tape layout for irrigation of sugarcane in latosol. Open Biotech J 2015; 9: 265-71.

\section{(C) Huang et al.; Licensee Bentham Open.}

This is an open access article licensed under the terms of the Creative Commons Attribution-Non-Commercial 4.0 International Public License (CC BY-NC 4.0) (https://creativecommons.org/licenses/by-nc/4.0/legalcode), which permits unrestricted, non-commercial use, distribution and reproduction in any medium, provided the work is properly cited.

\footnotetext{
* Address correspondence to this author at the Guangxi University, Nanning 530004, China; Tel: +86-771 2185896; Fax: +86-771 2185010; E-mail:
} gxhuangkai@126.com. 